\title{
A COMPARATIVE STUDY OF RURAL ATHLETES OF FOUR STATES OF INDIA
}

\author{
D. P. BHATNAGAR and R. GREWAL \\ Department of Human Biology, Punjabi University, Patiala, INDIA
}

\section{INTRODUCTION}

The success of an athlete depends upon his fitness with respect to the requirements of his particular physical activity. Many authors have studied the morphological and physiological fitness of athletes (Novak et al, 1978; Carter, 1970; Slaughter et al, 1980; Cureton et al, 1980; Morrow et al, 1978; Sodhi, 1976; Sidhu et al, 1975; Grewal and Bhatnagar, 1982); but there is little information regarding the rural athletes, however, Bhatnagar 1980, studied the rural athletes of Madhya Pradesh.

The present study was conducted to study the morphological variables of rural athletes of four states of India.

\section{MATERIAL AND METHOD}

Data on 22 rural men athletes of four states (Punjab 5, Haryana - 5, Assam - 4, Madhya Pradesh - 8) of

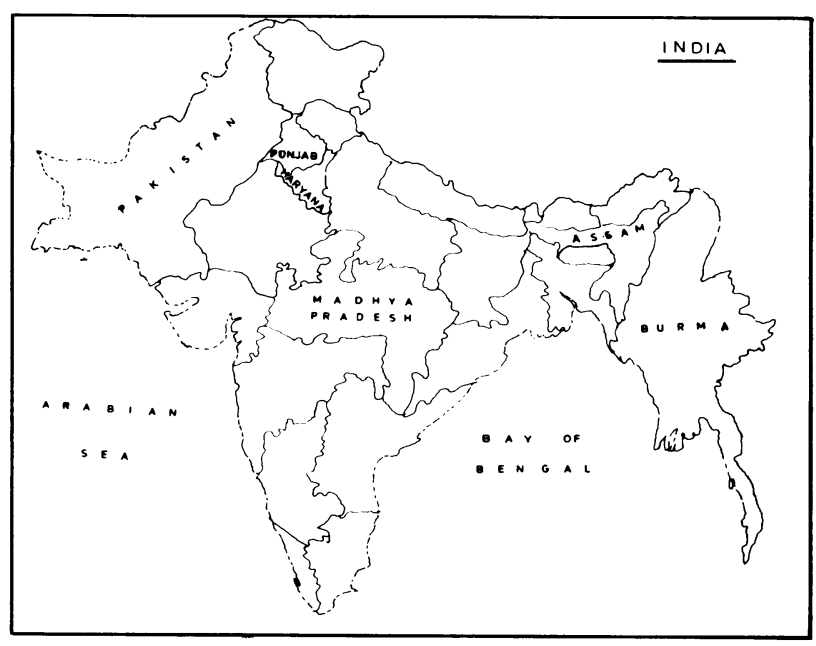

TABLE I

Mean, SD \& SEM of the various anthropometric variables of athletes from the Punjab, Haryana, Assam \& Madhya Pradest

S.No. Measurement

1. Weight $-\mathrm{kg}$

2. Height - cms

3. Sitting height $-\mathrm{cms}$

4. Biacromial diameter - cms

5. Bicristal diameter - cms

6. Ankle diameter - $\mathrm{cms}$

7. Chest circumference $-\mathrm{cms}$

8. Upper arm circumference cms

9. Fore arm circumference cms

10. Circumference at navel cms

11. Thigh circumference $-\mathrm{cms}$

12. Calf circumference $-\mathrm{cms}$

13. Biceps skinfold $-\mathrm{mm}$

14. Triceps skinfold $-\mathrm{mm}$

15. Mid axillary skinfold $-\mathrm{mm}$

16. Juxta nipple skinfold $-\mathrm{mm}$

17. Supra-iliac skinfold - $\mathrm{mm}$

18. Subscapular skinfold $-\mathrm{mm}$

19. Thigh skinfold $-\mathrm{mm}$

20. Calf skinfold $-\mathrm{mm}$

21. Wrist diameter $-\mathrm{cm}$

22. Humerus diameter $-\mathrm{cm}$

23. Femur diameter $-\mathrm{cm}$
(No. 5)

(No. 5)

Athletes of Haryana Mean \pm SD \pm SEM

61.80

169.80-

11.81

87.08

8.18

39.70

26.20

66.96

90.32

3.87

2.50

11.06

0.20

7.05

26.98

$$
3.47 \quad 1.55
$$

25.08

$2.37 \quad 1.06$

72.24

$\begin{array}{ll}5.28 & 2.36\end{array}$

50.00

33.68

10.16

10.70

8.76

7.40

12.92

12.00

20.40

14.24

5.62

6.64

9.44 $\begin{array}{ll}5.02 & 2.24\end{array}$

$\begin{array}{ll}2.66 & 1.19\end{array}$

$\begin{array}{ll}5.88 & 2.63\end{array}$

$4.32 \quad 1.93$

$3.57 \quad 1.59$

$3.20 \quad 1.43$

$6.65 \quad 2.97$

$3.74 \quad 1.67$

$9.39 \quad 4.20$

$4.89 \quad 2.19$

$0.40 \quad 0.18$

$\begin{array}{ll}0.39 & 0.17\end{array}$

0.50

0.22
Mean \pm SD \pm SEM

60.40

169.90

85.66

7.16

$4.26 \quad 1.90$

37.64

28.46

3.391 .51

$1.04 \quad 0.46$

6.78

$3.59 \quad 1.60$

87.08

$0.49 \quad 0.22$

$4.33 \quad 1.93$

26.72

$2.55 \quad 1.14$

$\begin{array}{lll}24.72 & 1.29 & 0.57\end{array}$

73.00

50.52

$\begin{array}{ll}4.78 & 2.14\end{array}$

33.12

$2.54 \quad 1.13$

6.48

$\begin{array}{ll}1.66 & 0.74\end{array}$

8.50

$2.79 \quad 1.25$

8.32

$\begin{array}{ll}4.00 & 1.78\end{array}$

6.84

8.36

11.60

\begin{tabular}{ll}
1.17 \\
\hline
\end{tabular}

$\begin{array}{ll}1.74 & 0.77\end{array}$

$3.68 \quad 1.64$

13.40

$3.52 \quad 1.57$

9.40

$4.33 \quad 1.93$

5.72

$4.02 \quad 1.79$

6.66

0.130 .06

9.44

0.180 .08
(No. 4)

Athletes of Assam

Mean \pm SD \pm SEM

156.60

167.88

87.07

37.25

26.70

6.80

82.88

23.87

23.75

$2.51 \quad 1.25$

$6.93 \quad 3.46$

$3.18 \quad 1.59$

$2.94 \quad 1.47$

0.850 .42

$\begin{array}{ll}0.14 & 0.07\end{array}$

$2.46 \quad 1.23$

$0.47 \quad 0.23$

73.42

$0.50 \quad 0.25$

46.88

$\begin{array}{ll}2.66 & 1.33\end{array}$

32.70

$\begin{array}{ll}.65 & 0.82\end{array}$

4.12

0.44

5.50

$0.65 \quad 0.32$

5.92

5.30

$0.57 \quad 0.28$

$\begin{array}{ll}0.78 & 0.39\end{array}$

5.40

$\begin{array}{ll}0.42 & 0.21\end{array}$

8.95

10.12

0.580 .29

6.77

$0.1 \quad 0.05$

$\begin{array}{lll}5.33 & 0.12 & 0.06\end{array}$

$\begin{array}{llll}6.50 & 0.25 & 0.12\end{array}$

8.82 $n=2828$ (No. 8)

Athletes of M.P.

Mean \pm SD \pm SEM

$\begin{array}{lll}52.43 & 5.21 & 1.84\end{array}$

$\begin{array}{lll}166.05 & 5.19 & 1.83\end{array}$

$\begin{array}{lll}85.15 & 2.81 & 0.99\end{array}$

$\begin{array}{llll}39.94 & 2.04 & 0.72\end{array}$

$\begin{array}{lll}26.32 & 0.90 & 0.31\end{array}$

$\begin{array}{lll}6.96 & 0.34 & 0.12\end{array}$

$\begin{array}{lll}82.93 & 4.89 & 1.72\end{array}$

$25.00 \quad 1.75 \quad 0.62$

$23.94 \quad 1.57 \quad 0.55$

$\begin{array}{lll}69.07 & 3.57 & 1.26\end{array}$

$\begin{array}{lll}44.49 & 1.99 & 0.70\end{array}$

$\begin{array}{llll}31.32 & 1.65 & 0.58\end{array}$

$\begin{array}{lll}4.32 & 1.32 & 0.46\end{array}$

$\begin{array}{lll}5.66 & 1.57 & 0.55\end{array}$

$\begin{array}{llll}6.99 & 2.11 & 0.74\end{array}$

$\begin{array}{llll}5.60 & 0.98 & 0.34\end{array}$

$\begin{array}{llll}6.10 & 1.08 & 0.38\end{array}$

$\begin{array}{lll}8.84 & 2.05 & 0.72\end{array}$

$\begin{array}{lll}8.81 & 2.56 & 0.90\end{array}$

$\begin{array}{lll}6.06 & 2.60 & 0.92\end{array}$

$\begin{array}{llll}5.40 & 0.19 & 0.06\end{array}$

$\begin{array}{llll}6.35 & 0.26 & 0.09\end{array}$

$\begin{array}{lll}9.05 & 0.29 & 0.10\end{array}$ 
India were collected among the participants of All India Rural Sports Festival held at N.I.S. Patiala in 1971. All the individuals in the present study were in the age of 17-25 years. The control sample (Sidhu and Phull, 1974) on 22 normal healthy rural boys in Patiala and have been utilised. 23 anthropometric variables as mentioned in Table I, were recorded on all the subjects. Comparison among athletes of different states and control could be carried out only in 13 measurements enlisted in Table II.

From a geographical point of view the subjects living in villages of Punjab and Haryana are from states situated in the foothill plains of the Himalayas. Similarly Madhya Pradesh is situated in the foothill plains of the Madadeo hills in the centre of India. Assam is a hilly area. There is no difference in specific ethnic groups in any of these states. Similar types of nutrition are taken in Punjab Haryana and Madhya Pradesh but not in Assam.

\section{RESULTS}

In the present paper an attempt has been made to compare the rural athletes of four states, viz. Punjab, Haryana, Assam and Madhya Pradesh and rural controls. The data were subjected to statistical treatment for mean, standard deviation and standard error of mean (Table I) and test of significance by ' $\mathrm{t}$ ' test (Table II).

Table I enlists various statistical constants on the athletes of four states of India. The results have been studied for 23 anthropometric variables i.e. weight, height, sitting height, six diameters, six circumferences and eight skin and subcutaneous tissue folds.

1. Weight: Rural athletes (Table I) of Punjab have been found to be heaviest $(61.80 \mathrm{~kg})$ followed by athletes of Haryana $(60.40 \mathrm{~kg})$ and of Assam $(56.50 \mathrm{~kg})$ and of Madhya Pradesh $(52.43 \mathrm{~kg})$. When these were compared among themselves (Table II) statistically significant differences could be observed between control and athletes of Punjab, Haryana and Assam, and between the athletes of Madhya Pradesh and Haryana.

2. Height: Athletes of Punjab and Haryana have been found to be almost of equal height (Table 1). Athletes of Assam and Madhya Pradesh have been observed to be stocky. When test of significance was applied (Table II) statistically significant differences could not be observed in any of the two groups.

3. Sitting height: Rural athletes of Punjab and Assam show almost similar sitting heights (Table 1). Athletes of Haryana and Madhya Pradesh present smaller sitting heights. It gives an indication that lower extremities are biggest in athletes of Haryana, followed by Punjab, Madhya Pradesh and Assam. Table II shows statistically significant differences only between control and rural athletes of Punjab.
TABLE ॥

The values of ' $t$ ' for various anthropometric variables of athletes of four states and control

\begin{tabular}{|c|c|c|c|c|}
\hline & Assem & $\begin{array}{l}\text { Madhya } \\
\text { Pradesh }\end{array}$ & Punjab & Haryana \\
\hline & \multicolumn{4}{|c|}{ WEIGHT } \\
\hline Madhya Pradesh & 1.83 & - & - & - \\
\hline Punjab & 0.97 & 1.68 & - & - \\
\hline Haryana & 1.14 & $2.20^{\circ}$ & 0.23 & - \\
\hline \multirow[t]{2}{*}{ Control } & $3.26^{*}$ & 1.59 & $2.44^{*}$ & $3.19^{*}$ \\
\hline & \multicolumn{4}{|c|}{ HEIGHT } \\
\hline Madhya Pradesh & 0.47 & - & - & - \\
\hline Punjab & 0.38 & 0.92 & - & - \\
\hline Haryana & 0.51 & 1.46 & 0.02 & - \\
\hline \multirow[t]{2}{*}{ Control } & 0.63 & 0.23 & 1.09 & 1.09 \\
\hline & \multicolumn{4}{|c|}{ SITTING HEIGHT } \\
\hline Madhya Pradesh & 1.03 & - & - & - \\
\hline Punjab & 0.00 & 0.97 & - & - \\
\hline Maryene & 0.64 & 0.28 & 0.62 & - \\
\hline \multirow[t]{2}{*}{ Control } & 1.74 & 0.92 & $2.20^{*}$ & 0.98 \\
\hline & \multicolumn{4}{|c|}{ BIACROMIAL DIAMETER } \\
\hline Madhya Pradesh & 0.80 & - & - & - \\
\hline Punjab & 1.33 & $2.82^{*}$ & - & - \\
\hline Haryana & 0.25 & $1.99^{*}$ & 1.70 & - \\
\hline \multirow[t]{2}{*}{ Control } & 0.27 & 0.83 & $2.59^{*}$ & 1.67 \\
\hline & \multicolumn{4}{|c|}{ BICRISTAL DIAMETER } \\
\hline Madhya Pradesh & 0.73 & - & - & - \\
\hline Punjab & 0.79 & 0.21 & - & - \\
\hline Haryana & 1.06 & 1.31 & 1.35 & - \\
\hline \multirow[t]{2}{*}{ Control } & $3.05^{*}$ & $2.78^{\circ}$ & 1.90 & $2.03^{*}$ \\
\hline & \multicolumn{4}{|c|}{ CHEST CIRCUMFERENCE } \\
\hline Madhya Pradesh & 0.02 & - & - & - \\
\hline Punjab & $2.20^{*}$ & $2.06^{*}$ & - & - \\
\hline Haryana & 1.84 & 1.61 & 0.88 & - \\
\hline \multirow[t]{2}{*}{ Control } & $4.92^{*}$ & $3.84^{*}$ & $4.52^{*}$ & $5.47^{*}$ \\
\hline & \multicolumn{4}{|c|}{ UPPER ARM CIRCUMFERENCE } \\
\hline Madhya Pradesh & 1.71 & - & - & - \\
\hline Punjab & $1.98^{*}$ & 1.19 & - & - \\
\hline Haryana & $2.45^{\circ}$ & 1.33 & 0.14 & - \\
\hline \multirow[t]{2}{*}{ Control } & $6.02^{*}$ & $5.09^{*}$ & $3.52^{*}$ & $4.47^{\circ}$ \\
\hline & & GH CIRCL & FERENC & \\
\hline Madhya Pradesh & $2.22^{*}$ & - & - & - \\
\hline Punjab & 1.31 & $2.35^{*}$ & - & - \\
\hline Haryena & $2.61^{\circ}$ & $4.54^{\circ}$ & 0.21 & - \\
\hline Control & $6.65^{*}$ & $4.71^{*}$ & $4.22^{*}$ & 8.12* \\
\hline & & LF CIRCU & ERENC & \\
\hline Madhya Pradesh & 1.89 & - & - & - \\
\hline Punjab & 1.61 & 1.78 & - & - \\
\hline Haryana & 0.49 & 1.91 & 0.39 & - \\
\hline Control & $3.81^{*}$ & 1.39 & $2.66^{*}$ & $3.25^{*}$ \\
\hline & & BICEPS SK & IFOLD & \\
\hline Madhya Pradesh & 0.36 & - & - & - \\
\hline Punjab & $2.28^{*}$ & $2.19^{*}$ & - & - \\
\hline Haryana & 1.83 & 1.62 & 1.26 & - \\
\hline Control & 1.71 & 0.99 & $2.00^{*}$ & 0.29 \\
\hline & & RICEPS S & NFOLD & \\
\hline Madhya Pradesh & 0.26 & - & - & - \\
\hline Punjab & 1.95 & $2.51^{*}$ & - & - \\
\hline Haryana & 1.67 & 1.52 & 0.84 & - \\
\hline Control & 2.33* & 1.41 & $2.08^{*}$ & 1.04 \\
\hline & & SCAPULA & SKINFOL & \\
\hline Madhya Pradesh & 0.15 & - & - & - \\
\hline Punjab & 1.83 & 1.74 & - & - \\
\hline Haryana & 1.69 & 1.59 & 0.17 & - \\
\hline Control & $2.00^{*}$ & $2.82^{*}$ & $3.14^{*}$ & $3.08^{*}$ \\
\hline & & PRA-ILIAC & KINFOL & \\
\hline Madhya Pradesh & 1.46 & - & - & - \\
\hline Punjab & $2.52^{*}$ & $2.28^{*}$ & - & - \\
\hline Heryana & 1.78 & 1.34 & 1.34 & - \\
\hline Control & $2.38^{*}$ & 0.76 & $2.14^{\circ}$ & 1.11 \\
\hline
\end{tabular}


4. Diameters: Six diameters - biacromial, bicristal, wrist, humerus bicondylar, femur bicondylar and ankle, have been studied for comparison among athletes of four different states living under slightly different ecological conditions especially Assamese as compared to Punjabi and Haryanavis. It has been observed that in most of the diameters athletes of Punjab and Haryana athletes present close affinities. Similar is the case with athletes of Assam and Madhya Pradesh. But former groups definitely have larger diameters as compared to latter groups (Table 1), which indicate greater sturdiness. When the results on biacromial and bicristal diameters were compared among subjects of different states and control on the statistical grounds (Table II). In the biacromial diameter statistical significant differences were found in athletes of Punjab and control. But in bicristal diameter control group differ from almost all the groups.

5. Circumferences: Results pertaining to six circumferences - chest, upper arm, fore-arm, navel, thigh and calf have also been studied (Table I). It has been observed that in most of the circumferences, athletes from Punjab show more value as compared to athletes of Haryana and Assam. Rural athletes of Assam show almost same magnitude of different circumferences as that of athletes of Madhya Pradesh. Results based on test of significance when examined pertaining to circumferences at the site of chest, upper arm, thigh and calf, statistically significant differences have been observed in most of the groups (Table II).

6. Skin and subcutaneous tissue folds: Observations pertaining to eight skin and subcutaneous tissue folds biceps, triceps, mid-axillary, juxta nipple, supra-iliac, subscapular, thigh and calf were also made (Table I). It was found that rural athletes of Punjab show maximum fat contents at all sites as compared with athletes of Haryana, Madhya Pradesh and Assam. Athletes of Madhya Pradesh and Assam show much less values of these parameters. The latter group especially has least fat content at most of the sites. Statistical tests were applied for comparison only pertaining to the four skin and subcutaneous tissue folds - biceps, triceps, subscapular and supra-iliac. Results indicate that control and athletes of Punjab always differ from each other. Some other groups also show statistically significant differences among themselves (Table II).

\section{SUMMARY}

In the present study 22 rural athletes of four different states of India have been studied for 23 anthropometric parameters - weight, height, sitting height, six diameters, six circumferences and eight skin and subcutaneous tissue folds. Rural athletes of Punjab and Haryana have been found to be comparable pertaining to all the anthropometric variables. Athletes of Madhya Pradesh show minimum values for most of the variables. The order of best anthropometry is athletes of Punjab and Haryana followed by Assam and Madhya Pradesh. Athletes of Madhya Pradesh are lacking behind in all the parameters except skin and subcutaneous tissue folds as compared to athletes of Assam.

\section{ACKNOWLEDGEMENTS}

Authors are thankful to Professor Dr. L. S. Sidhu, Dean, Faculty of Life Sciences and Mr. S. Anand, former JRF of Department of Human Biology, Punjabi University, Patiala. Authors are also thankful to the Director, N.I.S. Patiala.

\section{REFERENCES}

Anand, R., 1974 "Anthropometric studies in normal pre-school Punjabi children". Unpublished MD Thesis, Punjabi University, Patiala.

Bhatnagar, D. P., 1980 "Some morphological measures in athletes, volley-ball and kabaddi players of rural areas of Madhya Pradesh". J.Sports Med.\& Phys.Fit. 20: 109-112.

Carter, J. E. L., 1970 "The somatotypes of athletes - a review". Human Biology 42: 535-569.

Cureton, K. J. and Sparling, P. B., 1980 “Distance running performance and metabolic responses to running in men and women with excess weight experimentally equated". Med.Sci. in Sports \& Exercise 12: 288-294.

Grewal, R. and Bhatnagar, D. P., 1093 "A comparative study of volley-ballers of Assam and Madhya Pradesh". Hung Rev. Sports Med. (Hungary) 24 (1): 23-27.

Morrow, J. R., Jackson, A. S. and Bell, J. A., 1978 "The function of age, sex and body mass on distance running". Res.Quart. 49: 491-497.

Novak, L. P., Bestit, C., Mellerowicz, H. and Woodward, W. A., 1978 "Maximal oxygen consumption, body composition and anthropometry of selected Olympic male athletes". J.Sports Med.\& Phys.Fit. 18: 139-151. 
Phull, A., 1972 "Physical growth among Punjabi males of rural area". Unpublished MSc dissertation, Punjabi University, Patiala.

Sidhu, L. S. and Phull, A. K., 1974 "Patterns of physical growth in rural boys". Archives of Child Health 15: 220-232.

Sidhu, L. S., Kansal, D. K. and Kanda, B. S. 1975 "Anthropometric and roentogenogrammetric assessment of physique and body composition of athletes specialising in throwing events". J.Sports Med.Phys.Fitness 15: 192-198.

Slaughter, M. H. and Lohman, T. G., 1980 "An objective method of measurement of musculo-skeletal size to characterise body physique with applications to the athletic population". Medicine and Science in Sports \& Exercise 12: $170-174$.

Sodhi, H. S., 1976 "The physique and body composition of Indian athletes and sportsmen of selected physical activities". PhD Thesis, Punjabi Univ., Patiala.

Wells, C. L., Hecht, L. H. and Krahenbuhl, G. S., 1981 "Physical characteristics and oxygen utilisation of male and female marathon runners". Res.Quart. 52: 281-285.

\section{BOOK REVIEW}

Title: CURRENT CONCEPTS IN HAND SURGERY

Editor: John A. Boswick, Jr., Professor of Surgery, Chief, Hand Surgery Service, University of Colorado Health Sciences Center, Denver, Colorado

Publisher: $\quad$ Lea and Febiger, Philadelphia

Price: \$41.25 Hard back

287 pages plus index and numerous illustrations and tables

Perhaps because this book was birthed at the Rocky Mountain International Seminar on Hand Surgery in July 1982, its chapters reflect the effects of mountain air - bracing and vigorous in the main but suffering from high altitude sickness in others; the scientific nadir being the last chapter on Painful Hand Syndrome treated by Acupuncture, which is almost totally anecdotal and the references take no account of the excellent results obtained with the Guanethidine Bier manoeuvre. Perversely, the same author has written two excellent chapters on Tumours and Secondary Procedures after Replantation. The indications for replantation procedures are narrowing rapidly. The thumb is always worth replanting. Single fingers should not be reattached.

I was disappointed to see continued advocacy for split skin grafts in the chapter on finger tip injuries which do not expose bone, since this often results in a mental amputation of the affected digit because the sensation is always abnormal following such a procedure.

Nail bed injuries, frequently poorly managed, are satisfactorily dealt with and the treatment comprehensively described.

There is an excellent chapter on the difficult problem of the short metacarpal and its treatment.

There is a full cover of other aspects of hand surgery, including infections, burns, flexor tendons, and nerve and bone injuries, the crushed hand, rheumatoid disease and Dupuytren's contracture.

M. Pillet from Paris has a chapter on his excellent cosmetic prosthesis.

The spectrum of hand surgery is covered.

This book will delight all those who have an interest in hand problems and their management, and the Editor, John Boswick, is to be congratulated on organising such an attractive Meeting, especially out of the skiing season, and recording it so well.

B. Helal 